\title{
Kærlighedens umulighed
}

Af Kirsten HyldgaArd

\footnotetext{
Kun sand karlighed anerkender den Anden som Anden. Hvordan umuliggor kynisme, sentimentalitet og perversion karlighed?
}

Det, som den ene mangler, ligger ikke gemt $i$ den anden. Det er $i$ al sin enkelhed kerlighedens problem

(Lacan 1991, 53).

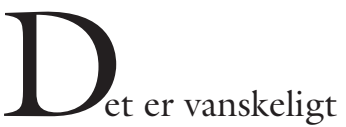

at tale og skrive om kærlighed, hvilket vedrører sagen selv, for kærlighed har sin Scylla og Karybdis, nemlig kynisme og sentimentalitet. Disse er to attituder, der undgår og endog benægter relevansen af spørgsmålet om kærlighed. Udgangspunktet skal her være, at hverken seksualdriften - som kynikere har en forkærlighed for at mene - endsige forelskelse - som sentimentale har en forkærlighed for at mene - kan være àrsag til kærlighed. Dermed hævdes ikke, at seksualdriften og forelskelse ikke vedkommer kærlighed; her skal ikke slås til lyd for den tese, der ofte synes at legitimere tematiseringen af kærlighed i filosofiske afhandlin- 
ger, nemlig at kærlighed er en problemstilling, der transcenderer lave kødelige lyster mod mere ophøjede, sublimerede luftlag, eros som stræben. Snarere vedrører pointen den velkendte erfaring af, at sex og erotik ikke er det samme, og at forelskelse gør blind i kraft af først og fremmest at være en narcissistisk dannelse. Populært sagt er forelskelse ren selvoptagethed i kraft af at vedrøre tilskrivning af idealer til den Anden, om hvem jeget menes at være eller gerne ville være. Det, som den forelskede ikke kan se, er den Anden qua Anden.

Og kærlighed er netop et forhold til den Anden qua Anden. Overvejelser over kærlighed munder ofte ud i overvejelser over forholdet til den anden overhovedet, altså et spørgsmål om sociale bånd $\mathrm{i}$ al almenhed. Sociale bånd er ikke nødvendigvis et forhold til den Anden qua Anden; den anden ses snarere som én selv, én man kan spejle sig i, blive bekræftet af, og én man kan rivalisere og konkurrere med. I så fald er den anden en anden i kraft af, at man kan sammenligne sig med ham.

Tilbagevendende formuleringer omkring kærlighed består i variationer over begrebet gensidighed. En lang tradition i fransk filosofi har derimod insisteret på at beskrive forholdet til den anden som mangel på gensidighed, som præget af asymmetri. Subjekter er enten slaver eller herrer (Kojève 1947), konflikt er væren-for-andres oprindelige mening (Sartre 1943), forholdet til den Anden er ikke et forhold i betydningen udgør en totalitet, forholdet er asymmetrisk (Levinas 1996, 1987; 86), og der eksisterer ikke noget seksuelt forhold (Lacan). Hvis et forhold angiveligt er symmetrisk og gensidigt, er talen et dække for, at en af parterne har veget for sit begær, en af kombattanternes begxr er blevet ruineret, ødelagt, den ene part har udbedt sig våbenhvile og har underkastet sig. Enhver tænkning af kærlighed, der hverken ønsker at forfalde til kynisk eller sødladen sentimental snak bør tage denne udfordring op, og det følgende skal da også forstås som en anerkendelse af disse beskrivelsers gyldighed, at en ide eller ideal om gensidighed umuliggør en beskrivelse af kærlighed.

\section{KÆRLIGHED VERSUS SOCIALE BÅND}

Hvis sagen skulle sættes på spidsen, kunne man hævde, at sociale bånd primært er homoseksuelle, for her forholder vi os til det lignende, det samme, rivaliserende og kæmpende om anerkendelse fra ligemænd. Kærlighed er til gengæld heteroseksuel, for her forholder vi os til det forskellige, det andet, det singulære. Ifølge Badiou (2000, 279) kan "kønsforskellen kun tænkes ved at bruge kærlighed som det forskelssættende kriterium." Kærlighed præsenterer, gør forskellen nærværende, den repræsenterer ikke forskellen som sådan. Heri ligger pointen i at tale om kærlighed, fordi her - til forskel fra sociale bånd overhovedet - er der ikke tale om et forhold til det lignende eller det samme, hvor forskellen blot er numerisk, men netop til den Anden qua Anden. Når sociale bånd her kaldes homoseksuelle og kærlighed heteroseksuel benægtes selvfølgelig ikke, at der kan være tale om kærlighed mellem personer af samme biologiske køn. 'Homo' og 'hetero' vedrører ikke valg af objekt (af samme køn eller andet køn) endsige et spørgsmål om identitet (homoseksuel, heteroseksuel, transseksuel). Lacan definerer et sted - her citeret efter hukommelsen - en heteroseksuel som én, der elsker kvinder. Lesbiske kan derfor udmærket være de egentlig heteroseksuelle, for så vidt de elsker den Anden som Anden, det vil sige ikke kun ser den Anden som driftens manipulerbare instrument for masturbation. Hvad der er afgørende for begreberne hetero- og homoseksuel er ifølge psykoanalysen ikke valg af objekt, men forholdet til kastrationen, det vil sige, hvorvidt den Andens mangel, den Andens andethed anerkendes eller ej.

Det skal heller ikke her benægtes, at man kan tale om kærlighed mellem forældre og børn og mellem venner, at et begreb om 
næstekærlighed ikke skulle kunne give mening, men det hævdes - på baggrund af psykoanalysens teser - at denne afseksualiserede kærlighed qua afseksualiseret er en afledning af netop den seksuelle. For at det giver mening at tale om kxrlighed som et forhold til den Anden qua Anden, er det grundlæggende et spørgsmål om forholdet til kønsforskellen, og forholdet til kønsforskellen er ifølge psykoanalysen et forhold til kastrationen, der igen er et spørgsmål om, at den Anden mangler, ikke er hel. Forholdet til kønsforskellen og kastrationen er grundformen, hvorfra alle andre former for kærlighed er afledet, heri inklusive kærligheden til den absolutte Anden, Gud. Opdagelsen af og forholdet til kønsforskellen er kærlighedens afsæt og grundform - fra Platons Symposion til Lacan.

\section{DER FINDES IKKE NOGET SEKSUELT FORHOLD}

I Lacans tese om, at "der ikke findes noget seksuelt forhold", ligger accenten på forholdet snarere end på det seksuelle. 'Forhold' vil sige alle variationer over gensidighed, at vi enten skulle kunne komplettere hinanden, være hinandens bedre halvdele, at to halvdele skulle kunne udgøre en totalitet, eller en totalitet bestående af to antagonistiske, rivaliserende, hinanden bekrigende parter. Pointen er også hos Badiou blevet formuleret på den måde, at forholdet mellem kønnene er “disjunktivt”, hvilket i matematikken peger på de tilfælde, hvor to mængder ingen fælles elementer har, der er tale om enten/eller. At forholdet mellem kønnene er disjunktivt er en tese, der fremsættes imod den gængse - sentimentale måde, hvorpå kærlighed tænkes, nemlig som foreningsmængden, som en erfaring af at blive forenet, at to mennesker bliver eet $k ø d$, som foreningen af to komplementære mængder, der herefter udgør et symmetrisk hele, en totalitet, en mængde der herefter kan tælles som en. $1+1=1$. Her er ikke kun tale om dårlig aritmetik, her er tale om den universelle fantasi om forholdet mellem kønnene siden Adam og Eva. Fantasien findes også i Aristophanes' tale i Platons Symposion, hvor den ene del af myten består i, at mennesket oprindeligt var en androgyn kugle, der herefter blev skåret i to halvdele. Siden har hver enkelt halvdel længtes efter at finde tilbage til sin bedre halvdel. Som Levinas $(1996,253)$ så rigtigt har bemærket, så taler denne myte ikke om en længsel efter den Anden, men om en længsel efter at vende tilbage til sig selv. Der er altså ikke tale om en længsel efter den andens andethed, tværtimod. Når vi længes efter at finde vore bedre halvdele, ja, så leder vi efter én at spejle os i, én der kan bekræfte en fantasi om at være hel.

Er der noget kærlighed ikke gør, så er det at gøre hel. Badiou har derfor fremsat det nærliggende forslag, at kærlighed frem for en erfaring af at blive forenet skal tænkes som erfaringen af at være To, en sætning der ækvivalerer Lacans sætning om, at der ikke findes noget seksuelt forhold. ${ }^{1}$ En sådan erfaring kan for det første ikke bestå i at udgøre et par. Der kræves som minimum tre tal for at kunne tælle til to; et par anerkendes fra en tredje position som i de tilfælde, hvor en ny kæreste bliver præsenteret for familie og venner. Hvis man betragter sig selv som del af et par, betragter man sig selv fra en tredje position, der formodes at overskue situationen. Parforhold har som sådanne intet med kærlighed at skaffe, parforhold er sociale institutioner.

Når man derimod taler om kærlighedserfaring, indtager ingen af parterne den førnævnte tredje position, begge er snarere in medias res, indfældet i situationen uden mulighed for at træde udenfor for at få et globalt overblik over situationen. Hvad kærlighed angår er man nødvendigvis part i sagen. Omvendt kan man heller ikke stå udenfor som tredje mand og afgøre, om der er tale om kærlighed i et bestemt partikulært parforhold. Kærlighed som erfaring er ikke noget, der kan objektiveres, noget man kan vide om og frelde domme over. 


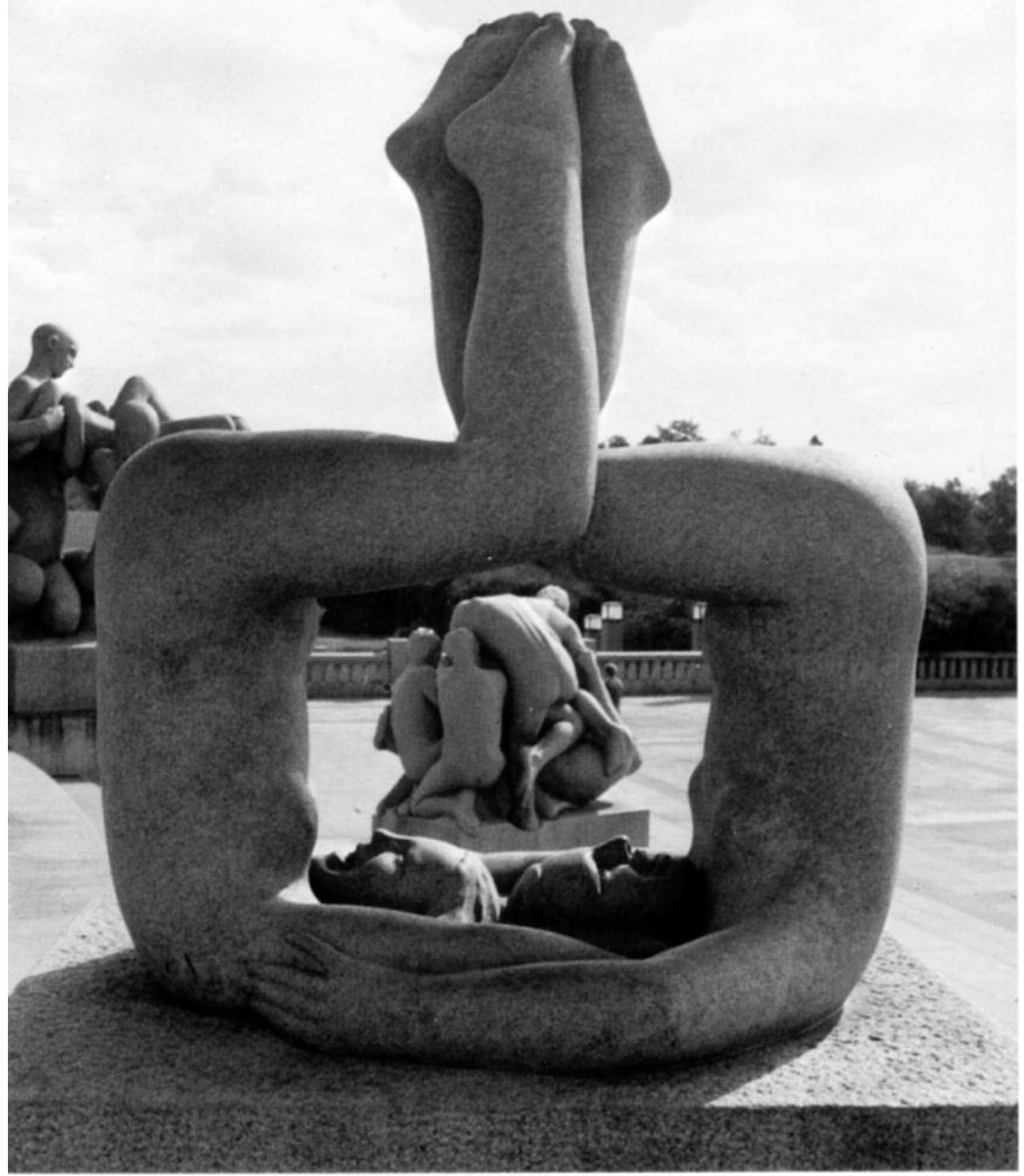

Gustav Vigeland: Figurgrupper i Frognerparken i Oslo. 
Kærlighed kan aldrig have status af videnskabeligt erkendelsesobjekt. Når videnskabsmænd bliver bedt om at tale om kærlighed, ja, så psykologiserer de - gentagelse af infantile relationer - eller de biologiserer - hormonernes hærgen, genernes gabestok. De klogeste af dem melder pas og henviser til digterne eller filosofferne.

Men at kærlighed ikke er noget, vi kan have viden om, ikke er noget der kan gøres til objekt for et videnskabeligt blik, er ikke et spørgsmål om, at kærlighed er en mystisk, uudsigelig erfaring. Netop filosoffer, digtere og kunsten $i$ al almindelighed giver denne erfaring mæle. Men erfaring - til forskel fra erkendelse - vedrører netop subjektet, ikke objektet. Erfaring kan kun artikuleres i et 1. person perspektiv. Erkendelse er derimod et 3. person perspektiv. Videnskabelig erkendelse må for at være objektiv sætte parentes om det erkendende subjekt qua subjekt, jævnfør anonyme procedurer og eksperimentets gentagelighed. Men at man, hvad andres kærlighed angår, aldrig kan vide, skyldes, at der ikke findes objektive kriterier, nødvendige og tilstrækkelige betingelser for at afgøre om et kærlighedsforhold nu også er et virkeligt sådant - og ikke blot et praktisk arrangement eller måske ligefrem et prostitutionsforhold. Der er mange - let forståelige og forklarlige grunde til at omgås andre i såkaldte kærlighedsforhold: som værn mod ensomhed, som værn mod dén økonomiske og sociale usikkerhed, der engang kunne gøre diamanter til en kvindes bedste ven, og endelig som praktisk foranstaltning med henblik på honorering af driftslivets krav. Men disse grunde - hvor forståelige og legitime de end er - kaldes ikke kærlighed.

Med erfaring menes også, at kærlighed ikke producerer viden, selvom erfaringen uden tvivl tvinger én til at tænke. At tænke og at akkumulere viden er ikke det samme. Man lærer ikke noget i betydningen at ruste sig til fortsat at have en heldig hånd $\mathrm{i}$ spillet eller imod at begå de samme fejl gang på gang. Man ved ikke mere om situa- tionen og den anden, hvis man skulle havne i den igen. I den forstand lærer man ikke af sine erfaringer. Erfaringen af kærlighed er snarere erfaringen af mangel på viden om den anden og situationen overhovedet - i denne forstand vedrører erfaring subjektet, ikke objektet. Kærligheden er ikke en mulighed $\mathrm{i}$ betydningen et valg af fortolkning $\mathrm{i}$ situationen. Snarere er kærlighed noget, der indvaderer os og sårer os (Levinas 1987, 88-89)

Tesen om, at seksualitet ikke kan være årsag til kærlighed, peger ikke på, at kærlighed skulle være tårnhøjt hævet over tilsvarende lave usublimerede kropslige lyster. Distinktionen mellem begreberne drift og begær er her nødvendig til fremstilling af, hvad der kan menes med den Andens andethed. Det særlige ved andre mennesker til forskel fra alle andre objekter i denne verden er, at man ikke kun er intentionelt rettet mod den Anden som objekt, at andre mennesker ikke kun er manipulerbare objekter, at man ikke kun kan forholde sig instrumentelt til den anden og de andre. Man kan naturligvis bestræbe sig på det $\mathrm{i}$ den videnskabelige erkendelse eller gøre den anden til slave, udbytte den andens arbejdskraft, prostituere den anden. Men den anden er også et subjekt, eller rettere, den anden kan vise sig som et subjekt. Pludselig kan der ske det, at man ser sig selv med den andens øjne, at man ser sig selv som et objekt for den Anden, at man bekymrer sig om, hvad den Anden måtte tænke om én, og hvad man er for den Anden. Den Anden er uigennemsigtig. Man kan ikke vide, hvad man er for den anden, men man kan gøre den ubetvivlelige og umiddelbare erfaring, at den Anden ikke blot er et 'intentum' for en bevidsthed eller et manipulerbart objekt, man kan forholde sig strategisk til. Når der ikke er tale om kærlighed, kan man opretholde forestillingen om sig selv som en isolerbar størrelse, et indre jeg eller selv over for den anden som en ydre ting, man kan forholde sig erkendende, kontrollerende, forførende, manipulerende og strategisk til. 
Denne sikre position rystes af erfaringen af kærlighed.

En måde, hvorpå man kan holde sig den Andens andethed fra livet, består i at se den anden som en, der mangler det, man har at give. Man mener at vide, hvad den anden mangler: social sikkerhed, penge og viden. Man har noget at give. Det nødvendige formynderi mellem forældre og børn og mellem lærere og elever kunne være eksempler. Opdragelse og uddannelse handler selvfølgelig om, at nogen i udgangspunktet formodes at have noget, andre mangler viden og diverse kompetencer $\mathrm{i}$ forhold til at begå sig i komplicerede sociale spil. I den klassiske patroniserende, paternalistiske attitude mener man at give det, man har, at man har noget, den anden mangler. Dette har imidlertid intet med kærlighed at skaffe af den enkle grund, at kærlighed snarere er at give det, man ikke har, for den Andens andethed er ikke en mangel på noget, man kan fylde ud; og det, man selv mangler, er ikke skjult i den Anden. Den Andens andethed er snarere det, der ikke kan kontrolleres, bemestres og begribes, det der ikke kan repræsenteres i klichéer om den anden, det uforudsigelige og overraskende ved den anden.

\section{KYNISME}

Kynisme og sentimentalitet er to måder, hvorpå denne mangel på viden kan benægtes, to måder hvorpå den andens status som subjekt kan benægtes. For kynikeren er kærlighed en illusion. Kynikeren er reduktionist, kærlighed er blot et illusorisk dække for kødets banale trang. Kxrlighed er seksualitet; at hævde andet er udtryk for overspændt føleri, kærlighed er en sublimeret version af seksualdriften, der tjener artens overlevelse. Vi er hildet i illusioner, når vi taler om begrebet kærlighed, som om det havde en reference. Dette har indflydelse på kynikerens forestillinger om seksualitet: Seksualitet er et behov på linje med føde og væske. Seksualitet tjener et formål, et repro- duktivt formål, nemlig artens overlevelse. Kærlighed er blot en omvej til målet: den reproduktive seksualitet. At mennesket også er natur, også er et dyr fremsættes som om der er tale om en dristig påstand.

Herved letter kynikeren sig for spørgsmålet om kærlighed. Det kølige kyniske blik foregiver at vide om den Andens begær og kan let konstatere, at det da ikke er tilfældigt, at mænd gennemsnitligt betragtet gifter sig med kvinder, der er yngre, smukkere, tjener færre penge og har lavere social status end dem selv. Den mandlige part har det, den kvindelige part mangler, hvorfor de fleste xgteskaber således er fornuftsægteskaber, og hvori skulle så den store forskel bestå mellem et regulært forhold til en prostitueret og et forhold til en såkaldt respektabel kvinde, lyder kynikerens berettigede udfordring. I alle tilfælde er der tale om sex til gengxld for social sikkerhed. Der er ingen grund til at være naiv, og før man begynder at mene, at dette er at drive sagen til urimelige yderligheder, kan man forsvare det sociologiske blik med at konstatere, at der i dag er et påfaldende højt antal veluddannede, økonomisk uafhængige kvinder, der ikke blot lever alene, men også lever i cølibat - tilsyneladende ikke af princip, men i praksis.

Men hvorom alting er, sætter kynikeren sig til rette ved skolemesterens kateder, kynikeren er en besserwisser, en mr. know-all. Kynikerens bornerthed viser sig imidlertid i det forhold, at han ikke ser sig i stand til at anerkende, at han fundamentalt er udelukket fra at vide, om der er tale om kxrlighed i dette eller hint tilsyneladende praktisk arrangerede forhold.

\section{Sentimentalitet}

Den sentimentale tænker forholdet mellem kønnene som et forhold. Den anden er i stand til at komplettere, udfylde subjektets mangel i betydningen at tilfredsstille den andens ønsker. Den ene har det, som den anden mangler. Aristophanes er med andre 
ord den ærke-sentimentale. Nøglebegreber for sentimentalitet er omsorg og gensidighed. Kærlighed er her angiveligt baseret på anerkendelse af den anden som en autonom person, hvis ideer og interesser er lige så vigtige som ens egne. Forholdet er præget af gensidig afhængighed, ikke af gensidig trælbinding. Den gensidige tilskrivning af værdi befordrer elskernes gensidige selvrealisering (Frie 1997, 207). Hvorfor skal denne parafrase tjene som indbegrebet af sentimentalitet? Hvordan kan nogen være uenige i et sådant ideal om gensidighed? Det kan man af den enkle grund, at det implicit hviler på en antagelse om, at det er muligt at have viden om begxret, hvis dette er, hvad der menes med "interesser" og "selvrealisering." Denne beskrivelse af forholdet til den Anden kunne ses som en variation over det amerikanske udtryk for at være 'supportive'. At være 'supportive' har to faldgruber: enten at underkaste sig den andens sag, gøre den andens sag til sin - kvinden bag manden, hvor tvetydigheden i denne underkastelse viser sig i mistanken i forhold til, hvem der egentlig har ambitioner på hvis vegne - eller at sætte sig $\mathrm{i}$ en utilsløret vidensposition $\mathrm{i}$ forhold til hvad den andens projekt overhovedet er eller burde være, og hvad der er godt for den anden - mesterens diskurs, den alfaderlige attitude. At vide hvad der er godt for den anden hænger ofte snævert sammen med at sætte hindringer op for den andens partikulære måde at opnå lyst på eller i afsvækkede versioner i form af den tvangsmæssige tilbøjelighed til at overdænge hinanden med kærligt mente gode råd, som forældre, lærere, ægtefæller, venner uophørligt gør, altså fortæller hinanden - i den bedste omsorgsfulde mening naturligvis - hvad der er godt for den anden, hvorefter det let kan konstateres, at de gode råd har været som at slå vand på en gås. At give andre gode råd kan tjene som flugt fra at skulle lytte til den Anden. At anerkende ens mangel på viden om den Andens begær er en forudsætning for overhovedet at lytte til den Anden.
Ønskeopfyldelsens niveau giver os et valg mellem at underkaste os eller at underkaste den anden. Når man 'ved hvad man vil', når man er 'assertiv' forveksles begær med ønskeopfyldelse, hvilket er i direkte modstrid med, hvad man kan lære af psykoanalysen, hvor begæret altid er i den Andens felt og derfor altid transcenderer viden.

Når ideen om gensidighed er kritisabel skyldes det først og fremmest, at den fremmer ideen om elskerne som hinandens spejlbilleder; man ser kun de billeder af sig selv, som man ønsker. Gensidighed levner ikke rum for det fremmedartede, tvetydige, forvirrende, overraskende, måske endog ubehagelige og rystende ved den Andens begxr. Og med den Andens begxr menes her såvel andetheden ved den konkrete Anden som andetheden ved én selv. Derfor simuleres der, derfor roses den andens præstationer. Når prostituerede og folk i al almindelighed simulerer, så forsikrer de den anden om, at der er tale om gensidighed, at der findes et seksuelt forhold. Idealet om gensidighed, perfekt symmetri kvæler ethvert tilløb til forskel eller singularitet - og med forskel og singularitet menes som sagt alt, hvad der er fremmedartet, tvetydigt, forvirrende, overraskende og måske endog ubehageligt og rystende ved såvel én selv som ved den Anden. Når man kompletterer den anden i symmetriske relationer, er der ikke levnet rum for begæret. Det sædvanlige resultat er som nævnt, at den ene part vil identificere begæret med den andens sag, vige for begæret ved at underkaste sig den andens prioriteringer eller $\mathrm{i}$ det mindste parforholdenes endeløse og uundgåelige kampe desangående og ikke mindst de udtalte eller skrevne kontrakter og xgtepagter. Denne blindgyde slipper man kun ud af, hvis man følger Lacans distinktion mellem ønsker og begær og med andre ord ikke identificerer begæret med et fænomenologisk begreb om begær, det vil sige et begær, der er intentionelt, rettet mod et objekt. Begæret er snarere begrebet for selve negativiteten i en forestillet ønskeopfyldelse. 
Ifølge psykoanalysen er kærlighed tilsyneladende et spørgsmål om en illusion i kraft af at være et spørgsmål om overføring. Men ifølge Lacan er det langt fra så simpelt, at overføring hos Freud blot skulle være et spørgsmål om falsk kærlighed. Det, der adskiller en analytisk tilgang til spørgsmålet om overføring fra en terapeutisk ditto, er, at overføringens illusion ikke er en fejltagelse, der skal korrigeres, hvor analytikeren i så fald er garant for, hvad der er virkelighed. En sådan indstilling finder man i den kognitive, adfærdskorrigerende terapi. I den analytiske praksis er det illusoriske ved kærligheden snarere en privilegeret anledning til, at sandheden kan vise sig, subjektets sandhed vel at mærke, altså et sandhedsbegreb der ikke vedrører et spørgsmål om forestillingens overensstemmelse med en ydre virkelighed.

Kærligheden og det seksuelle forhold "ophører ikke med ikke at kunne skrives" ifølge Lacan (1975, 132). Men hvad tjener den dobbelte negation i beskrivelsen af manglen på seksuelt forhold til? Hvorfor ikke blot skrive 'det kan ikke skrives' eller 'det kan ikke repræsenteres'? To negationer annullerer ikke nødvendigvis hinanden, snarere fremstilles en "umulighed". Ethvert seksuelt møde er nødvendigvis en ikke-intenderet fiasko - i forhold til forholdet som standard, naturligvis. Sætningen drejer sig ikke blot om at fremsætte et faktum; det drejer sig om en umulighed, der hjemsøger os.

Imidlertid dækker det kontingente, mirakuløse kærlighedsmøde denne umulighed til - "det ophører med ikke at kunne skrives”. Elskere har altid haft problemer med begreberne kontingens og nødvendighed 'nødvendighed' skrevet som “det ophører ikke med at kunne skrives." Det synes at være en fornærmelse at informere elskere om, at de med kausalitetens nødvendighed gentager infantile relationer eller kæmper en benhård kamp for at overføre deres gener til kommende generationer. Hvis mødet på ingen måde er kontingent, snarere determineret og derfor et spørgsmål om nødvendighed, tæller det ikke som kærlighed. Omvendt føler elskere sig ikke bedre tilpas ved mødets angivelige tilfældighed à la: 'hvis du var ankommet til festen en time senere, ville jeg være gået hjem med en anden'. Elskere fejrer det tilfældige møde, som om skæbnen (den Anden) var på spil. De fejrer, at det tilfældige møde er alt andet end kontingent, snarere en nødvendighed, og at nødvendigheden er mirakuløst kontingent. Kxrlighed synes med andre ord at være et begreb, der bestræber sig på at gøre det umulige, nemlig at favne to korrelative begreber i et: kontingens som nødvendighed. Kærligheden - "det ophører ikke med ikke at kunne skrives" svæver i uvished, vakler mellem kontingens og nødvendighed.

Ifølge Lacan $(1975,132)$ møder man intet andet i partneren end symptomer og affekter, af alt det som i enhver markerer sporet af eksilet fra det seksuelle forhold. Men det er dog trods alt noget - altså at møde den andens symptomer og affekter. Grunden til, at den neurotiske benægtelse og den perverse fornægtelse er så afgørende problemstillinger i psykoanalysen, er, at benægtelser og fornægtelser er mekanismer, der tjener det formål at udelukke muligheden for at anerkende sporet af den Andens andethed, at udelukke muligheden for et møde med den Andens andethed; neurosen og perversionen repræsenterer to variationer over 'ikke at ville vide af' denne andethed. Sand kærlighed er derfor anerkendelse af det seksuelle forholds umulighed.

Hvad kynikere ikke kan fatte er, at erfaringen af kærlighed, af at være To, ikke er forelskelsens upassende overvurdering af forskellen mellem en mand og en anden. Man elsker ikke det udvalgte objekt, fordi han ubetvivleligt er et geni, eller den smukkeste mand i verden, eller verdens største elsker. Han har da nok nogle respektable kvaliteter, man da godt kan oprulle, hvis man skulle blive afkrævet en forklaring af en undrende offentlighed. Men man må sam- 
tidig indrømme, at den slags kvaliteter er der flere, der sidder inde med, og det har ikke været nok til at få en til at elske dem alle. Kærlighed motiveres ikke ved objektets kvaliteter, og man kan ikke gøre sig fortjent til kærlighed. Man kan muligvis gøre sig fortjent til at være et driftsobjekt ved hjælp af silikoneimplantater, profileret muskulatur og make up teknik, men ikke til at blive elsket. Hos Lacan synes den kristne kxrlighedstanke at klinge med, det vil sige en kærlighed, der tænkes som værende spontan, umotiveret, at man ikke kan gøre sig fortjent til den Andens kærlighed. ${ }^{2}$

Der er ikke nogen årsag til kærlighed, kærlighed kan ikke forklares. Kærlighed er en akt, den Anden bliver "ophøjet til tingens niveau". "Jeg elsker dig, for af uransagelige grunde elsker jeg noget ved dig, der er mere end dig". 3

Grunden til, at man elsker den Anden, er hverken begrundet i ydre eller formodede indre kvaliteter - for "det er noget ved dig, der er mere end dig". Dette 'noget', kaldet objekt $a$, er ikke nogen ting, men heller ikke intet. Dette 'noget' er ikke driftens partialobjekter, de imaginære størrelser, der træder til som eftertragtelsesværdige - de fyldige læber, de barkede næver, ulvesmilet. Dette 'noget' er snarere begxrets objekt. Objekt $a$ tilhører både-og og hverken-eller subjektet eller objektet. Det betegner på en gang andetheden hos den Anden og det mest intime ved subjektet. Det viser sig altid 'andetsteds', uden for subjektet og undslipper dets greb. Kærligheden er en privilegeret erfaring af den klassiske subjekt-objekt dikotomi som en spændetrøje, for kærlighed kan hverken begrundes ved subjektet (forstået som idealistisk skabende og (over)vurderende) eller ved objektet (realismens væsentlige kvaliteter eller mangel på samme), kun ved den Anden.

\section{Noter}

1. Se også Levinas (1996, 115)

2. Se Nygren, Anders (1965)

3. Lacan, J.: Les quatre concepts fondamentaux de la psychanalyse, Seuil, Paris, 1973, p. 241. Se også Miller, J.-A. Miller: Extimité, upubliceret seminar 1985-86.

\section{LITTERATUR}

- Badiou, Alain (2000): "What is Love", in Renata Salecl (red.): Sexuation, Duke University Press, Durham and London.

- Frie, Roger (1997): Subjectivity and Intersubjectivity in Modern Philosophy and Psychoanalysis,

Rowman \& Littlefield Publishers, Inc., Boston, Maryland.

- Kojève, A. (1947): Introduction à la lecture de Hegel, Gallimard, Paris.

- Lacan, J.: Problèmes cruciaux pour la psychanalyse, upubliceret seminar.

- Lacan, J. (1991): Le séminaire livre VIII. Le transfert, Seuil, Paris.

- Lacan, J. (1973): Le séminaire livre XI. Les quatre concepts fondamentaux de la psychanalyse, Seuil, Paris.

- Lacan, J. (1975): Le séminaire livre XX. Encore, Seuil, Paris.

- Levinas, E. (1987): Time and the Other, Duquesne University Press, Pittsburgh, Pennsylvania.

- Nygren, Anders (1965): Eros og Agape, Munksgaard, København.

- Totalitet og Uendelighed (1996): Hans Reitzels Forlag A/S, København.

- Sartre, J.-P.: L'être et le néant, Éditions Gallimard, Paris 1943.

\section{SUMMARY}

Rather than being an object of scientific knowledge, love is a matter of experience. The article proposes that love, true love, recognizes the Other as Other. Cynicism and sentimentality are two variations on the theme of not recognizing the Other as Other. Furthermore, love presents, it does not represent, sexual difference, love is an experience and a recognition of 'there being no such thing as a sexual relationship' (Lacan).

Kirsten Hyldgaard, ph.d. Lektor, Institut for Pædagogisk Filosofi, DPU 